\title{
26 \\ CREATING THE NYPD COUNTERTERRORISM BUREAU
}

\author{
Michael A. Sheehan ${ }^{1}$
}

Two months after the 9/11 attacks, while the World Trade Center was still smoldering, Michael Bloomberg was elected mayor of New York. Bloomberg, through his appointment of Police Commissioner Raymond Kelly, set into motion a process that would revolutionize the New York City Police Department's (NYPD) approach to counterterrorism.

This chapter tells the story of the creation of the NYPD's Counterterrorism Bureau (CTB) and its two principal components: the Counterterrorism Division (CTD) and the NYPD contribution to the Federal Bureau of Investigation's (FBI) Joint Terrorism Task Force (JTTF). The leadership and determination of the people who founded and staffed these units set the tone for an effective and reasonable post-9/11 approach to counterterrorism for a local police department.

\section{Laying the groundwork}

Mayor Bloomberg was a successful businessman with an unrelenting drive to accomplish tasks quickly and efficiently. He sought strong subordinate leaders to whom he could give general guidance but were expected to perform with excellence and autonomy. Bloomberg would turn out to be the ideal mayor for the NYPD. The department made great strides in both counterterrorism and crime fighting during Bloomberg's three terms. Even when it was not politically popular, Bloomberg remained a stalwart supporter of the NYPD.

One of Bloomberg's first and most important appointments was Police Commissioner Kelly. Kelly had been commissioner during the first World Trade Center attack in 1993, when the department had only a peripheral role in counterterrorism via a handful of detectives assigned to the FBI's JTTF. By the time Kelly took office, the implications of that bombing and its link to the 9/11 attacks convinced Kelly that New York City remained a principal target of al-Qaida's strategic ambitions.

The New York JTTF supported the Southern District of New York's prosecution of the perpetrators of the 1993 attack. Ramzi Yousef, the mastermind of that attack, was convicted in absentia and arrested in Pakistan in $1995 .^{2}$

In the interim, however, Yousef and his uncle, Khalid Sheikh Mohammed, plotted Operation Bojinkaa plan to blow up a dozen aircraft over the Pacific Ocean. A test run of their plan partially succeeded. Yousef left a small bomb on a Japan Airlines plane that exploded in midair on the Manila to Tokyo bound flight, killing one passenger and injuring another. The pilot skillfully landed the severely damaged aircraft at Naha Airport on Okinawa. ${ }^{3}$ Yousef and Mohammed managed to escape the Manila police, but Yousef 
was later arrested in Pakistan (thanks in part to the State Department's Rewards for Justice program), while his uncle made his way to Afghanistan. ${ }^{4}$

It was then, as a result of Mohammed's plotting with al-Qaida chief Usama bin Ladin, that the 9/11 operation was conceived - a hybrid of the 1993 World Trade Center attack and Operation Bojinka. ${ }^{5}$ Due to its experience with the 1993 attack, the Department of Justice's Southern District of New York took the lead for the investigation and prosecution of international terrorist attacks for the federal government. New York officials already had experience operating internationally. In the wake of al-Qaida's U.S. Embassy bombings in Kenya and Tanzania in 1998, the New York JTTF joined a team of intergovernmental specialists to investigate the attacks. In 2000, they joined a team sent to Yemen to investigate the bombing of the USS Cole. ${ }^{6}$

These interagency teams, known as Foreign Emergency Support Teams, were led by the State Department's Office of Counterterrorism—which by late 1998 was headed by Ambassador Michael A. Sheehan. ${ }^{7}$ John O'Neill, a special agent in charge of the New York JTTF, led the FBI contingent of the team, comprised of investigators and forensic experts. Concurrently, the Southern District of New York managed the U.S. government's prosecutorial expertise on al-Qaida.

By the mid-1990s, the Central Intelligence Agency (CIA) had begun to understand the developing threat of Bin Ladin and al-Qaida. In 1996, for the first time in its history, the CIA established a "virtual station" focused on an individual-Bin Ladin—as opposed to a country. This unique organization was established within the Directorate of Operations at the CIA under David Cohen, who would later become the NYPD's commissioner for intelligence. ${ }^{8}$

In 1998, in the immediate wake of the U.S. Embassy bombings in East Africa, Secretary of State Madeleine Albright appointed Sheehan as the State Department's ambassador-at-large for counterterrorism. At the suggestion of President Bill Clinton's counterterrorism czar, Richard Clarke, Sheehan visited John O'Neill within his first week on the job. Sheehan returned to Washington with a much fuller understanding of the pending al-Qaida threat.

At the same time, Kelly was appointed as the commissioner of the U.S. Customs Service. Under his watch, Customs conducted an extremely successful counterterrorism interdiction. In late December 1999, during the peak of the so-called millennium threat associated with the year 2000, authorities arrested the "Millennium Bomber," an al-Qaida operative named Ahmed Ressam who attempted to smuggle 130 pounds of explosive material into the United States. ${ }^{9}$ He planned to attack Los Angeles International Airport with a suitcase bomb around the millennium celebrations.

An alert customs agent foiled Ressam's plot. The agent viewed Ressam acting nervously and ordered him to a secondary inspection site where agents inspected his vehicle's trunk. Authorities subsequently arrested Ressam. Ressam had been trained, indoctrinated, and sent by al-Qaida from its camps in Afghanistan to Montreal, Canada, where he became part of an operational cell. ${ }^{10}$

At the same time, al-Qaida was planning to attack the USS The Sullivans in the port of Aden in Yemen. The attack faltered and was postponed until October 2000, when al-Qaida successfully attacked a different U.S. warship, the USS Cole, when it sailed into the port of Aden for resupply. ${ }^{11}$ The Ressam plot and other intelligence indicating that al-Qaida had planned a series of attacks around the millennial celebrations made clear to the Washington counterterrorism community that al-Qaida was a serious and growing threat. Nevertheless, even after the October 2000 attack on the Cole, few recognized that threat in its entirety.

Yet many counterterrorism officials who had experience with al-Qaida prior to 9/11, including the NYPD's future leadership-Kelly at Customs, Sheehan at State, and Cohen at the CIA-were part of a small number of counterterrorism officials who recognized both al-Qaida's dangers and limitations. In managing their counterterrorism programs, the NYPD sought to aggressively and relentlessly prevent a future al-Qaida attack while at the same time avoiding trampling the civil liberties of its citizens or instilling an overwrought fear that would inhibit people from visiting, living within, or investing in New York City. 


\section{The Counterterrorism Bureau}

Upon assuming leadership of the NYPD for the second time, Kelly quickly went to work to build the city's counterterrorism capability from scratch. He created two separate but complementary organizations: the Counterterrorism Bureau and a completely revamped Intelligence Division. Kelly tapped Frank Libutti, a retired Marine lieutenant general from the Pentagon's office of counterterrorism, to build and run the CTB and CIA veteran David Cohen to build and run the new Intelligence Division. ${ }^{12}$ Intelligence and operations would work together to protect the city from another attack.

Kelly was not alone in trying to figure out how the NYPD would evolve after 9/11. Among those were a young police captain, Michael O'Neil. Like many of his NYPD colleagues, O'Neil spent the first three months following the $9 / 11$ attack on "the pile," leading a portion of the rescue and recovery effort commonly referred to as the "Bucket Brigade." While working the pile, O'Neil thought about what could be done beyond cleaning up the attack site. He authored a white paper that envisioned the NYPD expanding its mission to include counterterrorism intelligence and training functions. His paper was forwarded up the chain of command around the time Kelly took charge. In short order, O’Neil was assigned to help develop the CTB.

Building the new capability would have been challenging under any circumstance, but Kelly had to build it while the NYPD was cutting 17\% of its force. In the last part of Rudy Giuliani's term as mayor, the police department had swelled to 41,000 uniformed police officers in an effort to decrease crime, but it was an unsustainable number of personnel. Kelly had to reduce the size to 34,000 officers while at the same time building a new counterterrorism capability. ${ }^{13}$ This is notable because most police departments wait until additional state or federal resources are provided before committing to counterterrorism functions. For local police, crime fighting is paramount, and they defer counterterrorism to the FBI. Kelly could not wait, and he managed to find the resources to establish the CTB while shrinking the NYPD.

The key to Kelly's success was his selection of personnel. He took the risk of going outside of the NYPD to hire veterans of the federal government as commissioners for the CTB and Intelligence Division. Below those commissioners, he picked maverick, aggressive NYPD officers who knew how to finish tasks and had strong track records of success.

\section{The Counterterrorism Division}

The two major components of the CTB were the Counterterrorism Division and the NYPD component of the JTTF. Kelly understood investigations were the heart of offensive counterterrorism operations. They are designed to detect or deter persons with violent intent before they can launch an attack. At the same time, Kelly also recognized he needed to "harden" the city with a defensive approach that would make it more difficult for terrorists to attack. Both became functions of O’Neil's Counterterrorism Division.

In January 2002, just days after Kelly's appointment, O’Neil was put in charge of the then non-existent Counterterrorism Division, a command at least two levels above his rank of captain. Kelly also assigned Inspector John Colgan, a talented officer with extensive logistics, administrative, and budgetary experience, to the CTD headquarters. Colgan was considered a renegade. He graduated from the elite Regis High School on Manhattan's Upper East Side and had attended the U.S. Coast Guard Academy.

Colgan spent most of his career in administrative and training assignments, and he was supremely efficient in navigating the complex world of government funding and budgets. He was the perfect fit for a bureau that started from scratch but needed to grow quickly. Colgan was single minded in his efforts, trampling over any obstacle in building the CTD.

As for a home for the new unit, O'Neil knew of a converted warehouse in the city's hinterlands that had been recently gutted and renovated. It had fluorescent lights, new chairs, computers, carpeting, and, perhaps most importantly, a huge parking lot. The unit now had a home, but it still needed to define its 
mission and recruit the right personnel. O'Neil sought the best talent from within the NYPD, and many were eager to join the new division after seeing 23 of their comrades killed on $9 / 11 .{ }^{14}$

Thousands applied. O'Neil established a rigorous interview process to identify the best and brightest. Former crime prevention personnel were assigned the new challenge of protecting critical infrastructure, the best police instructors became counterterrorism instructors, and uniformed officers who had military intelligence backgrounds became strategic threat analysts. As the unit and mission took form, O'Neil determined that it was going to take unusual organizational agility and the right people to get the job done.

The unit grew around a polyglot crew of cops with backgrounds as former narcotics detectives and military reservists. These cops were supplemented with new support provided by sharp, young civilian analysts, many with master's degrees from the most respected universities in the world. The new unit was established "on the fly" at a speed the federal government could only envy.

O'Neil also had connections to the growing number of reservists returning from Afghanistan (and later Iraq) and pulled them into the unit as well. One included NYPD Captain O'Rourke, who had recently completed his 12-month activation with the Air Force Office of Special Investigation's Counterterrorism Watch Center. As an Air Force reserve major, he had worked in a Sensitive Compartmented Information Facility reading Secret and Top Secret reports on Sunni Islamist terrorist groups. O'Rourke was set to return to a patrol precinct in the South Bronx, but O'Neil had other ideas. O'Neil told him to stop by the warehouse prior to his first day back in the Bronx, made a few calls, and O'Rourke was assigned to the unit within hours.

About one year into the development of the CTB, the Department of Homeland Security recruited away its first chief, Frank Libutti, to serve as an undersecretary in the new department. ${ }^{15}$ Michael A. Sheehan, who had recently served as the ambassador-at-large for the State Department's Office of Counterterrorism, replaced him.

In its first few years, the CTD developed seven units/functional areas: 1) Terrorism Threat Analysis Group; 2) Threat Reduction Infrastructure Protection Section; 3) Training Section; 4) the Chemical, Biological, Radiological, Nuclear, and Explosive (CBRNE) Preparedness Section; 5) Special Projects Unit; 6) NYPD Shield; and 7) the bomb section. Many functions crossed multiple sections and required the entire staff to be flexible and collaborative.

\section{Terrorism Threat Analysis Group}

Most armchair strategists are familiar with Sun Tzu's famous quote regarding the importance of knowing your enemy as well as yourself. ${ }^{16}$ Although Sun Tzu's wisdom seems obvious, many of the purported counterterrorism experts that proliferated on the cable news networks after 9/11 had only a superficial understanding of al-Qaida. New York City needed to strike a careful balance that warned people of the al-Qaida threat while at the same time promoting confidence for people to live, visit, and invest in the city.

To strike this balance, the NYPD needed a deep and nuanced understanding of al-Qaida - such as the group's strengths and weaknesses - to gain a realistic assessment of how the group might be able to attack New York City again. The NYPD's message to the public was clear: "There is a significant threat—but we are managing it. You can help us by communicating." In the weeks after 9/11, O'Neil set up a hotline with the now-ubiquitous saying: "If you see something, say something." 17

The detectives within the CTD and the JTTF were expected to become al-Qaida experts, which required detailed study of their modus operandi, leadership, and ideology. One of Kelly's other successful actions was to authorize the hiring of civilian analysts, many straight out of Ivy League graduate programs, since the NYPD lacked the expertise. Understanding the threat guided the CTD's defensive and "hardening" initiatives.

Until the civilian analysts arrived at the NYPD, detectives within the threat unit were primarily responsible for writing one-page Terrorism Awareness Bulletins that alerted police officers to evolving terrorist 
threats. The new civilian analysts were a diverse group, but all had experience studying and analyzing terrorism. They shared a similar mindset as well and did their best to integrate into the police culture. They were housed together in a small room at the warehouse, each with their own desk and quiet space to "think about terrorism."

From day one, it was a surprisingly easy assimilation. They became the Terrorism Threat Analysis Group and initially offered input and more pointed analysis for the Terrorism Awareness Bulletins. The detectives at the CTD welcomed them, and they appreciated the insight that the "smart kids" provided. For their part, the analysts readily consumed the street smarts and practical knowledge of the detectives. It seemed like both sides of the analyst-cop partnership had been eagerly awaiting one another, and together they figured out the pieces of the threat puzzle in New York City quickly, efficiently, and effectively.

With the "smart kids" on the team, the Terrorism Threat Analysis Group expanded beyond the onepage bulletins and started publishing longer reports that focused on how terrorists conducted their operations. The first volume covered eight of the major terrorist attacks against the United States, including the first World Trade Center attack, the Oklahoma City bombing, the Cole bombing, and the Madrid train attack. The second volume covered 14 additional attacks and plots against New York City, including plots against the Brooklyn Bridge and the subway system.

The third volume included a compendium of terrorist plots that involved improvised weapons of mass destruction (WMD), including the Aum Shinrikyo attack in the Tokyo subway system, the 2001 anthrax attacks in New York City, and a plot using ricin in the United Kingdom. It also included the chemical disaster in Bhopal, India, given the NYPD's concern with chemical storage facilities in the city and the desire to understand the dynamics of a potential attack on these facilities.

Daniel Rudder, a young scholar the NYPD hired from Colombia University, also published an in-depth report on the history of al-Qaida's ideology. ${ }^{18}$ This report dispelled cartoonish depictions of the jihadi narrative and described a much more sophisticated and compelling justification for religious violence in defense of the Islamic community that was purportedly under attack, particularly from the United States and Israel. The CTD used the volumes for training. ${ }^{19}$ O'Neil also tasked one of his new civilian analysts to create a counterterrorism library with the most up-to-date books on terrorism, physical security, and WMD. The library also included a media room that monitored international news outlets.

But perhaps the group's biggest coup was establishing a Sensitive Compartmented Information Facility at the Brooklyn headquarters. ${ }^{20}$ This enabled the analysts to have direct access to Secret-level government documents. The Department of Homeland Security was supportive but slow and bureaucratic, so a handful of NYPD reserve military officers with Top Secret clearances managed a deal with Naval Intelligence to certify the physical and operational standards of the facility before the Department of Homeland Security eventually certified it.

By acquiring a nuanced understanding of al-Qaida's true capabilities - both its strengths and weaknesses - the NYPD struck a balance in its counterterrorism posture. It was a delicate balance, encouraging people to continue to live, invest, and travel to New York City while asking them to stay vigilant. Some areas, like Wall Street, were hardened extensively, but in other areas, it was appropriate to put away the white concrete road barriers that were an eyesore, disrupted traffic, and did little to protect some buildings. The NYPD resisted turning Manhattan into a walled compound.

\section{Threat Reduction Infrastructure Protection Section}

The largest section in CTD was the Threat Reduction Infrastructure Protection Section. This was a new function for the NYPD. The department previously had a small unit that aided businesses on "lights and locks" to deter criminal activity, but this unit was repurposed with the goal of protecting the critical infrastructure of the city from a sophisticated terrorist attack-a task of enormous breadth. Its first function was to assess the city's critical infrastructure and establish levels of priority based on importance and 
vulnerability. After assessing more than 300 locations, they prioritized the top 40, which included Times Square, Wall Street, Broadway, and Grand Central Station.

Early on, Kelly decided that threat and risk assessments would be a core capability for the CTD, but it was a steep learning curve for the detectives. They had to gain expertise quickly, so they brought in blast mitigation experts from the Cooper Union, an elite engineering school with a surprising level of expertise on the physics of explosives and the best means to mitigate their effects. Detectives also went to classes to learn how to create computer-aided design drawings so they could develop detailed schematics for security plans.

Based on recommendations resulting from the Threat Reduction Infrastructure Protection Section's assessment of key commercial locations and iconic structures, bollards were emplaced to protect building lobbies, glass standards were raised, security perimeters were extended, and closed-circuit television camera coverage was vastly expanded and improved. The unit worked closely with the U.S. Army Corps of Engineers on a multi-year project to identify vulnerabilities in the aging fleet of city bridges and tunnels, and they worked on ways to harden them from various methods of attack.

At the same time, the unit created small teams to work with private-sector entities that had materials that could be converted into improvised WMD. The NYPD recognized the threat from homegrown terrorists - perhaps a radicalized employee with access to dangerous materials. Teams of detectives inspected and worked with chemical companies to reduce the risk of theft, sabotage, or commercial accidents. Others worked closely with engineering firms and hospitals to better safeguard radiological isotopes.

Another significant contribution involved the construction of the Freedom Tower. After reviewing the initial plans, Sheehan was surprised by the vulnerability of the building to a terrorist attack. In response, he directed Colgan and O'Neil to draft a white paper addressing its vulnerabilities. Weeks later, in a meeting prompted by the governor, the building owner notified the NYPD that they planned to revise the building and incorporate many of the NYPD's recommendations, despite the significant costs associated with modifying a building they had already started constructing.

\section{Training Section}

The Training Section provided a range of training - from general counterterrorism awareness training for cops on the beat to sophisticated training for personnel assigned to deal with WMD. Having the right personnel was key to the success of this program. O'Neil recruited some of the best police instructors from within the department, including some who were teaching undergraduates in criminal justice at John Jay College in their off-duty time. The late Lieutenant John Rowland, a gifted instructor and leader, led the team. ${ }^{21}$

The training section spent long hours researching and writing lesson plans that would form the basis of their presentations. The trainers exposed NYPD officers to the terrorist operational cycle, taught skills in surveillance and detection, recreated explosive devices and vehicle bombs to expose identifiable "tells," and began the research to provide officers with chemical and radiological protective measures and equipment. Word spread of the CTD "course book," and in short order, members of other law enforcement agencies from the region showed up to take classes in the warehouse. These impromptu courses developed into some significant joint counterterrorism efforts that stretched from Maine to Maryland.

The training unit constantly sought to expand its expertise, and they were fortunate enough to be able to recruit a wide range of experts to assist them. One program that proved important and popular was a course taught by former CIA specialists on law enforcement "solicitation" of Muslims. They instructed NYPD detectives on Arab and Islamic cultural issues so as to avoid offending friendly sources of information. They also provided tips and techniques for the interrogation of hostile suspects.

The detectives merged these concepts with their years of interrogating criminal "perps" of all types. Unlike Hollywood portrayals, the best NYPD interrogators were calm, methodical, and patient. They had 
a gift for getting people to talk. Sometimes it took many days, but these detectives would eventually break through and get the suspect to provide reliable information.

\section{Chemical, Biological, Radiological, Nuclear, and Explosive Preparedness Section}

The CTD was acutely aware of al-Qaida's intention to acquire and deploy WMD against the U.S. homeland, including a fledgling anthrax program they had experimented with in Afghanistan. ${ }^{22}$ With the 9/11 attack still fresh, the nation was hit by an anthrax attack only weeks later, with the contaminated letters ultimately killing five and sickening 17 more. Although these attacks were eventually traced to a single individual with experience in the U.S. military's biological warfare program, the source of the attack was unknown for several years. ${ }^{23}$ The fear of a terrorist attack using improvised WMD was a real concern.

In response, the NYPD created a series of programs to counter the threat. As noted earlier, NYPD detectives had to develop expertise in the types of threats that could reasonably be launched against the city: chemical, biological, radiological, and explosive. The Department of Homeland Security had a robust funding program for counter-WMD efforts and was happy to support New York's efforts as a pilot program.

Colgan was relentless in driving the training program, and within two years, the NYPD had built a formidable counter-WMD response capability. The entire department received a modicum of training that enabled every officer to provide perimeter security for any disaster or attack. Ten thousand cops received "Level Three" training that enabled them to operate on the edges of contaminated areas. Finally, over 600 cops received "Level Four" training-basically operating in a "space suit" - that enabled them to enter the blast area of some of the most challenging disaster sites.

\section{Special Projects Unit}

By 2003 and 2004, the CTD was a hotbed of innovation, as the teams tried to anticipate likely al-Qaida attack modes and means to deter the attacks or mitigate the damage if an attack slipped past the city's defenses. O'Neil created a Special Projects Unit to fill operational gaps, innovate new defensive measures, and conduct special operations to identify the city's vulnerabilities.

The unit managed some of the division's most innovative programs. When a threat or vulnerability was identified, the CTD created capability to mitigate that threat with personnel, programs, and technologies. Their work was most visible during the Republican National Convention in 2004, which saw a half-mile buffer of concrete and vehicle barriers around Madison Square Garden that kept the convention impervious to vehicle-born threats.

Working out of the back room of the CTD warehouse known as the SWAMP (Secret Works and Mysterious Projects), the unit also conducted "red cell" operations. In these operations, they acted in the manner of terrorists to determine vulnerabilities and corresponding mitigation strategies. One such project was called “Operation Kaboom.” Three detectives were provided a credit card with a $\$ 7,000$ line of credit and a civilian phone and told to build a large bomb based on information available on the internet, without identifying themselves as police officers.

Six weeks later, the trio had built a 2,400-pound ammonium nitrate and fuel oil truck bomb and surreptitiously delivered it to a department facility where they "lit the fuse," all of which was recorded for future briefing and training. ${ }^{24}$ They built the bomb at a leisurely pace at a rental storage facility in the Bronx. The unknowing facility manager sauntered by one day and even offered to help them haul some bags of ammonium nitrate until he was politely ushered away.

The operation exposed problems with ammonium nitrate laws. This information and coordination with Congressional staff helped the push for stronger federal laws on the regulation of volatile chemicals that could be built into massive, improvised bombs (as was the case in the first World Trade Center and 
Oklahoma City bombings). In addition, ammonium nitrate vendors were made more sensitive to sales of these volatile chemicals to suspicious persons. ${ }^{25}$

The Special Projects Unit organized tabletop exercises, managed directly by Kelly, for incidents, such as a dirty bomb attack in downtown Manhattan. They were followed by field exercises that deployed teams with their protective gear to manage a simulated chemical or radiological attack site. The NYPD's biggest concern was the creation of an improvised radiological device derived from locally sourced isotopes from cancer hospitals or engineering firms. There were no federal protocols, and a BBC documentary, with advisory support from the British security services, suggested that contaminated personnel from a radiological attack should remain close to the attack zone and be showered before being released. ${ }^{26}$

The NYPD had doubts about this protocol, and there was no federal guidance on how to react to a radiological attack, so the Special Projects Unit reached out to two of the nation's nuclear labs-Brookhaven in Long Island and Sandia in New Mexico-for help. Their engineers built a mock city in the desert in the southwestern United States and tested the explosion of an improvised radiological bomb. The bomb emitted chunks of metal with gamma radiation that remained fairly close to the explosive area, perhaps within a few blocks. In addition, the radiological bomb emitted alpha and beta particles that attached to dust particles and floated with the wind direction.

The studies in the desert showed both types of contaminated particles would not be propelled as far as originally thought — as the weight of the floating particles brought the contaminated dust particles down to earth. After extensive engagement with these scientists, the NYPD decided that the most productive course of action after an attack would be for all personnel to immediately move as far away from the attack zone as possible, away from the "radioactive shine" of the heavier gamma particles. New York would not attempt to decontaminate personnel close to the attack zone as depicted in the BBC documentary.

Instead, police officers would direct people away from the blast zone and into the wind, thereby minimizing exposure to alpha and gamma particles floating in the air. People would then be instructed to go home, take off their clothes, put them in a garbage bag, and then take a shower. Alpha particles can be stopped by a thin layer of material, including dead skin, so they are only harmful if swallowed, inhaled, or absorbed through an open wound. ${ }^{27}$

Beta particles can be stopped by a thin sheet of aluminum but can penetrate the dead skin layer, causing burns; they can also pose an internal radiation threat if ingested or inhaled. ${ }^{28}$ Most of this type of contamination could be washed away harmlessly. Gamma radiation from explosive chunks was different-more akin to getting a giant x-ray blast. But, again, the NYPD's conclusions were to move as far away from the blast of the explosion as quickly as possible and seek medical treatment.

\section{NYPD Shield}

On July 7, 2005, a terrorist attack in London, commonly referred to as "7/7," shocked the world. Four suicide bombers detonated three bombs on London's subway system and a fourth bomb on a double-decker bus, killing 52 and injuring more than $700 .{ }^{29}$ In the wake of the attack, the NYPD expanded its outreach to private sector security elements within the city. Recognizing that the private sector had a major role to play in securing the city, the CTD created NYPD Shield, "an umbrella program for a series of current and future Police Department initiatives that pertain to private sector security and terrorism." ${ }^{30}$ Shield is a "public-private partnership based on providing best practices, lessons learned, counterterrorism training opportunities and information sharing." 31

Local private security personnel are often the true first responders to an attack. Many of the city's major corporations invested heavily in enhanced security measures after 9/11, and they were hungry for information, best practices, training, and any other assistance the NYPD could provide. Private-sector firms expanded closed-circuit television coverage and established operations centers, and some even employed 
dog units. The more sophisticated, high-profile companies used low-profile counter-surveillance personnel to watch over their properties and their corporate leaders.

The new program kicked off in late July 2005, with CTD officers providing a briefing on the London bombings to the city's security managers. Hundreds came to learn about the attack and its implications for New York City. The department was happy to provide updates, including a description of a new program of random bag checks at subway stations.

The NYPD gave each security manager a booklet listing different services that the department could provide (such as emergency text messages, e-mails, best practices, and opportunities for training). Many sectors-such as financial services, hotels, Broadway playhouses, concert venues, ferry operators, and hospitals - created their own consultative bodies. The NYPD engaged with as many businesses as possible, often in meetings chaired by Kelly, who took a keen interest in trying to resolve their issues. The security managers received this well, as they were able to address their issues and concerns directly to the commissioner.

Due to the vulnerability of New York to a London-style attack, where the bombers had carried bombs onto the city's transit systems in personal backpacks, the CTD wanted to implement a bag check program to deter a similar attack in New York. Kelly liked the idea and started the program. The chiefs devised a workable program that was deployed to subway stations throughout the city.

The concept entailed stationing small police units around key subway entrances to conduct "random" bag checks on passengers before boarding the train. It was not a big shock to New Yorkers, as they had to undergo similar security checks prior to entering Yankee Stadium or the U.S. Open Tennis Championship. Moreover, the London bombings made the previously unpopular idea of random bag checks more palatable. The execution of the plan included perfunctory bag checks of random subway riders but was augmented with targeted bag checks when plainclothes officers observed indicators of any terrorist activity, such as people carrying unusual bags (containing wires or fluids), passengers acting nervous around security personnel, or other "tippers."

The New York American Civil Liberties Union sued the NYPD over the program, and both Sheehan and Cohen spent hours being challenged by American Civil Liberties Union lawyers. But in the end, the NYPD won the case. ${ }^{32}$

\section{Bomb section}

A separate bomb section was created within the Special Projects Unit when O'Neil recruited a recently returned reserve Special Forces engineer to the unit. This unit was not to compete with the legendary NYPD bomb squad that responds to bomb threats ${ }^{33}$ but to provide the CTD in-house expertise on terrorism-related improvised explosives. At the Brooklyn facility, the bomb section built important mock-ups for training and educational purposes.

The first was an exact replica of the Ryder rental truck bomb used in the 1993 World Trade Center attack. The second was a mock-up of the bomb-making facility used by the 2005 London bombers. While the mock-up of the Leeds apartment looked like a meth lab, it had some important differences, and the CTD did not want their cops to miss a bomb factory by mistaking it for a drug lab.

By 2005, the CTD was a well-oiled machine with true experts running programs within their respective areas of responsibility. The CTD depended upon the initiative of its detectives to find ways to keep the city safe. At one point, Kelly, pleased with the productivity of the CTD, offered Sheehan 20 additional detectives. When Sheehan informed O’Neil about the offer, O'Neil replied, "Boss, I don't need 20 random guys. They'll give me more of an administrative headache than they would be worth. Just give me five of the best." ${ }^{34}$ He then handed Sheehan the list. Kelly supported the re-assignment despite the grumbling of those NYPD precincts that lost some of their best crime fighters. Again, it was the quality of personnel that made the difference for the innovative measures initiated by the CTD. 


\section{The NYPD contingent within the FBI's JTTF}

The FBI has 56 field offices across the United States, with headquarters in the major metropolitan areas. ${ }^{35}$ Although each office has its own organization, the FBI field office is typically divided into several divisions. The New York field office is typical of a large office, with its four divisions: administration, criminal (for organized crime, white-collar crime, public corruption, and kidnappings), counterintelligence, and the JTTF. $^{36}$

New York City was the home of the first JTTF, created in 1980 when an NYPD official and a special agent from the FBI's New York field office met to discuss how to stop a terrorist organization that was responsible for a series of violent attacks in the city. They agreed to pool their resources, creating the first JTTF. $^{37}$ This ad hoc, multi-agency organization morphed into a unit charged with tracking all terrorist groups operating within the United States.

Since then, and especially after $9 / 11$, JTTFs have proliferated to roughly " 200 , including at least one in each of the 56 FBI's field offices." 38 They are composed of locally based investigators, analysts, linguists, and other specialists from dozens of U.S. law enforcement and intelligence agencies. JTTFs "chase down leads, gather evidence, make arrests, provide security for special events, collect and share intelligence, and respond to threats and incidents at a moment's notice." ${ }^{39}$ The New York JTTF has representatives from the State Police, Immigration and Customs Enforcement, the Port Authority Police, and other law enforcement agencies. Aside from the FBI, the NYPD contingent is by far the biggest contributor of personnel to the task force.

Prior to 9/11, the NYPD contingent of the JTTF included 16 detectives, two sergeants, and a lieutenant-mostly within the domestic terrorism division and surveillance units. This group was tiny, however, compared to the more than 120 detectives and supervisors Kelly would ultimately assign after 9/11. Within weeks, Kelly assigned some of his best detectives to the JTTF. In addition to the 120-plus detectives, Kelly also assigned a one-star chief and several other senior officers. As they acquired their security clearances, these detectives enabled the NYPD to participate on all JTTF operations.

Kelly recognized that many plots targeting New York City originated outside the city, so he wanted his team to understand the terrorist threat across the nation and their overseas roots, as it had immediate implications for New York. Thus, he needed to have a large team detailed to the JTTF. Sheehan ensured they obtained the requisite clearances so they could access the most sensitive national intelligence available. This enabled NYPD detectives to read raw intelligence from the various national intelligence agencies at the JTTF.

This team briefed Sheehan every morning, who in turn briefed Kelly and Cohen-all of whom were longtime consumers of the most sensitive intelligence from their time in the federal government. They were very familiar with al-Qaida's global operations and determined to stay on top of the latest developments.

In addition, Cohen used his CIA contacts to get the agency's top analysts to periodically visit New York City to brief Kelly, Sheehan, and himself. This global understanding of the terrorist threat shaped the development of the NYPD's global programs in counterterrorism and intelligence.

Kelly tracked all of the important investigations through a detailed, daily brief with his deputy commissioners for intelligence and counterterrorism. Sheehan would brief the FBI cases, and Cohen would brief details of the NYPD cases run out of his offices. Kelly would typically spend up to an hour each morning with his two deputy commissioners, discussing the case details and other initiatives that needed be implemented to strengthen the city's ability to deter an attack. As he did with his other counterterrorism initiatives, Kelly selected the most creative and aggressive NYPD veteran officials for the JTTF.

NYPD detectives and FBI special agents differ from one another in many ways. The average detective assigned to the JTTF typically had 12 to 18 years of experience on the streets of New York, and many had conducted hundreds of street arrests, including arrests of violent criminals. The special agents often lacked this street experience, but they were generally more educated, and some had years of experience investigating 
al-Qaida, dating back to the 1993 World Trade Center bombing, the East Africa embassy bombings, and the Cole bombing. Although the NYPD and FBI leadership clashed at times, relations were generally good at the squad level, and a mutual respect developed between the detectives and the special agents.

Investigations normally entailed collecting information on suspects by using surveillance, informants, undercover agents, or cops; analysis of their phone records (numbers called-not the substance of the conversation); and analysis of their social media. To use wiretaps on phones or computers, or to access information from the National Security Agency, a warrant is required from a special judge on the Foreign Intelligence Surveillance Court, which governs the use of these special tools. ${ }^{40}$ The department would typically seek this type of warrant only if the suspects had discussed taking violent action.

If the team had grounds for criminal charges, they could request a grand jury to review the case, which normally entailed prosecutors from the U.S. Attorney's Office. When investigations identified serious persons of interest who sought to conduct violence, the JTTF squad would often introduce an informant or undercover officer to infiltrate. This often resulted in arrests when the fledgling plot was disrupted. Suspects often claimed that informants or under covers entrapped them, but those arguments rarely held in court. ${ }^{41}$ Some critics claim that some of these plots were fanciful in nature and never would have been conducted..$^{42}$ But prior to $9 / 11$, many would have called the plot to hijack airplanes and crash them into buildings ridiculous and pure fantasy.

\section{Conclusion}

This chapter described the creation of the NYPD's Counterterrorism Bureau and its Counterterrorism Division and contribution to the JTTF. The fact that many of the capabilities that Kelly and his team began building in 2001 remain to this day is a testament to the foresight of this team.

The importance of public-private partnership for countering terrorism was one particularly important outcome. Over the past 15 years, Shield has trained more than 100,000 personnel in courses related to active shooter incidents, terrorism awareness, detecting hostile surveillance, suspicious mail and packages, and vehicle-borne improvised explosive device recognition. Shield continues to provide e-mail alerts, unclassified intelligence assessments, monthly liaisons, table-top exercises and live drills, and quarterly conferences to its large team of security professionals. ${ }^{43}$

While some of these efforts have not been without controversy, such as claims of entrapment, they have been effective and prevented dozens of potential attacks against the city. While terrorists have not been successful at conducting another major attack against New York since 9/11, it is important that the NYPD remain vigilant and resist the temptation to divest from the counterterrorism capabilities that it has built over the past two decades.

\section{Notes}

1 The author is indebted to Michael O'Neil for his extensive suggestions and contributions to this chapter.

2 "The Long Arm of the Law: FBI International Presence Key to Bringing Terrorists to Justice," Federal Bureau of Investigation, February 6, 2004, https://archives.fbi.gov/archives/news/stories/2004/february/law020604.

3 Christopher S. Wren, "Plane Bombing Is Described in Terror Trial,” New York Times, June 4, 1996, www.nytimes. com/1996/06/04/nyregion/plane-bombing-is-described-in-terror-trial.html.

4 “Success Story: Ramzi Ahmed Yousef," Rewards For Justice, accessed September 30, 2020, https://rewardsforjustice. net/english/ramzi_yousef.html.

5 National Commission on Terrorist Attacks, The 9/11 Commission Report: Final Report of the National Commission on Terrorists Attacks Upon the United States (New York: W.W. Norton, 2004), 145-160.

6 Ibid., 74.

7 "Foreign Emergency Support Team," U.S. Department of State, accessed October 2, 2020, https://2001-2009.state. gov/s/ct/about/c16664.htm. 


\section{Creating the NYPD Counterterrorism Bureau}

8 National Commission on Terrorist Attacks, The 9/11 Commission Report, 109.

9 Josh Meyer, "Man Convicted of Taking Part in Bomb Plot," Los Angeles Times, April 7, 2001, www.latimes.com/ archives/la-xpm-2001-apr-07-me-48100-story.html.

10 U.S.A. v. Ressam, Petition (Supreme Court, 2007).

11 National Commission on Terrorist Attacks, The 9/11 Commission Report, 152-153 and 180.

12 Craig Horowitz, "The NYPD's War on Terror," New York Magazine, January 24, 2003, https://nymag.com/ nymetro/news/features/n_8286/.

13 Al Baker, "Crime Drops Despite Fewer Officers in Lean Times," New York Times, July 17, 2009, www.nytimes. com/2009/07/18/nyregion/18nypd.html.

14 “9/11 Tribute," New York City Police Department, accessed October 27, 2020, https://www1.nyc.gov/site/nypd/ about/memorials/9-11-tribute.page.

15 William K. Rashbaum, “Terror Expert With the City Police Is in Line for Federal Post,” New York Times, March 22, 2003, www.nytimes.com/2003/03/22/nyregion/terror-expert-with-the-city-police-is-in-line-for-federal-post. html.

16 Sun Tzu, The Art of War (London: Filiquarian, 2007).

17 For origin of the motto, see Hanson O'Haver, "How 'If You See Something, Say Something' Became Our National Motto," Washington Post, September 23, 2016, www.washingtonpost.com/posteverything/wp/2016/09/23/ how-if-you-see-something-say-something-became-our-national-motto/.

18 Patrice O’Shaughnessy, “New York's Secret War on Terror," New York Daily News, October 2, 2005.

19 Ibid.

20 Judith Miller, "FBI vs. the NYPD," New York Post, March 25, 2008, https://nypost.com/2008/03/25/fbi-vsthe-nypd/.

21 Roland died in January 2017 from an illness associated with his work on "the pile" after 9/11, another victim of the attack.

22 National Commission on Terrorist Attacks, The 9/11 Commission Report, 151.

23 Jackson Landers, "The Anthrax Letters That Terrorized a Nation Are Now Decontaminated and on Public View," Smithsonian Magazine, September 12, 2016, www.smithsonianmag.com/smithsonian-institution/ anthrax-letters-terrorized-nation-now-decontaminated-public-view-180960407/.

24 Al Baker, "Test Shows Ease of Buying Bomb Parts," New York Times, September 13, 2016, www.nytimes. com/2006/09/13/nyregion/13bomb.html.

25 Regulation of the Sale and Transfer of Ammonium Nitrate, 6 U.S.C. $\$ 488$ a (2007), www.law.cornell.edu/uscode/ text/6/488a\#: :text=The\%20Secretary\%20shall\%20regulate $\% 20$ the,Cybersecurity $\% 20$ and $\% 20$ Infrastructure $\% 20$ Security\%20Agency.

26 Dirty War, directed by Daniel Percival (2004, BBC One).

27 "Radiation Dictionary," Centers for Disease Control and Prevention, accessed November 14, 2020, www.cdc.gov/ nceh/radiation/emergencies/glossary.htm.

28 Ibid.

29 "July 72005 London Bombing Fast Facts," CNN, June 18, 2020, www.cnn.com/2013/11/06/world/europe/july7-2005-london-bombings-fast-facts/index.html.

30 “NYPD Shield," New York City Police Department, accessed December 10, 2020, www.nypdshield.org/public/.

31 Ibid.

32 Macwade v. Kelly, U.S. Court of Appeals, Second Circuit, August 11, 2006, https://caselaw.findlaw.com/us-2ndcircuit/1252582.html.

33 Richard Esposito and Ted Gerstein, "Inside the NYPD Bomb Squad," Police Magazine, September 1, 2007, www. policemag.com/339801/inside-the-nypd-bomb-squad\#: :text=The\%20Bomb\%20Squad\%20is\%20a,backed\%20 by $\% 20$ laboratory $\% 20$ forensic $\% 20$ science.

34 Quote is recollection of the author.

35 "Field Offices," Federal Bureau of Investigation, accessed September 30, 2020, www.fbi.gov/contact-us/ field-offices\#: : :text=Our\%20local\%20FBI\%20offices\%20are,the\%20U.S.\%20and\%20Puerto\%20Rico.

36 "FBI New York History," Federal Bureau of Investigation, accessed September 30, 2020, www.fbi.gov/history/ field-office-histories/newyork.

37 “Model Partnership: New York JTTF Celebrates 35 Years," Federal Bureau of Investigation, December 8, 2015, www. fbi.gov/news/stories/new-york-jttf-celebrates-35-years.

38 “Joint Terrorism Task Force," Federal Bureau of Investigation, accessed September 30, 2020, www.fbi.gov/investigate/ terrorism/joint-terrorism-task-forces.

39 Ibid. 
40 Elizabeth B. Bazen, The U.S. Foreign Intelligence Surveillance Court and the U.S. Foreign Surveillance Court of Review: An Overview, CRS Report RL 33833 (Washington, DC: Congressional Research Services, 2007), https://apps. dtic.mil/dtic/tr/fulltext/u2/a462105.pdf.

41 Francesca Laguardia, "Terrorists, Informants, and Buffoons: The Case for Downward Departure as a Response to Entrapment," Lewis \& Clark Law Review 17, no. 1 (2013): 171-214, https://law.lclark.edu/live/files/13718lcb171art4laguardiapdf.

42 Ian Cummings, "FBI Undercover Stings Foil Terrorist Plots-But Often Plots of the Agency's Own Making," Kansas City Star, March 2, 2017, www.kansascity.com/news/local/crime/article135871988.html.

43 Vincent Amadeo, "NYPD Shield and the Global Network: A Template for Law Enforcement Executives," Police Chief Online, February 26, 2020, www.policechiefmagazine.org/nypd-shield-and-the-global-shield-network/. 